\title{
SINZHI WARMIGUNA: NOTAS SOBRE POLÍTICA E GÊNERO ENTRE AS/OS SARAYAKU RUNA
}

\author{
Marina Ghirotto Santos (D)
}

Universidade de São Paulo. Programa de Pós-Graduação em

Antropologia Social I São Paulo - SP - Brasil 
Este artigo aborda relações entre (cosmo)política, liderança, território e gênero entre as/os Sarayaku Runa, povo kichwa da Amazônia equatoriana. Uma das traduções para "a política” é a expressão "hatun yuyayguna kwintanakuy", que significa "conhecimento e/ou grande/importante conversa" ou "conversatório". Dedico especial atenção a algumas mulheres líderes - puxadoras de conversatórios -, bem como a algumas das "coisas" que fazem e, ao mesmo tempo, as fazem, como a chagra (roçado) e a aswa (chicha ou cerveja de mandioca). Esta atenção sugere formas "femininas" e/ou de "mulheres" de territorializar o mundo e a política, deslocando a dicotomia moderna-ocidental do público como domínio da política e dos homens vs. privado/doméstico como o plano das mulheres.

Palavras-chave: cosmopolítica; gênero; mulheres kichwa; chicha; Amazônia equatoriana

\section{SINZHI WARMIGUNA: NOTES ON POLITICS AND GENDER AMONG THE SARAYAKU RUNA}

\section{ABSTRACT}

This article addresses relations between (cosmo) politics, leadership, territory and gender among the Sarayaku Runa, a Kichwa people from the Ecuadorian Amazon. One of the possible translations for "politics" is the expression "hatun yuyayguna kwintanakuy", knowledge and/or important/great conversation. I pay special attention to some leading women - "talktakers" -, some of the "things" they do and, at the same time, do them, such as the chagra (women's garden) and the aswa (chicha or manioc beer). This attention suggests "feminine" and/or "women's" ways of territorializing the world and politics, displacing the modern-western dichotomy of the public as the domain of politics and men vs. private/domestic as women's sphere.

Keywords: cosmopolitics; gender

\section{SINZHI WARMIGUNA: NOTAS SOBRE POLÍTICA Y GÉNERO ENTRE LAS/LOS SARAYAKU RUNA}

\section{RESUMEN}

Este artículo aborda las relaciones entre (cosmo)política, liderazgo, territorio y género entre los Sarayaku Runa, un pueblo kichwa de la Amazonía ecuatoriana. Una de las traducciones para "la política" es la expresión “hatun yuyayguna kwintanakuy”, conocimiento y/o grande/importante conversatorio. Dedico especial atención a algunas mujeres lideresas - impulsadoras de conversatorios -, a algunas de las "cosas" que hacen $\mathrm{y}$, al mismo tiempo, las hacen, como la chagra (huertos) y la aswa (chicha o cerveza de yuca). Este enfoque sugiere formas "femeninas" y/o "de mujeres" de territorializar el mundo y la política, desplazando la dicotomía moderna-occidental de lo público como el ámbito de la política y de los hombres vs. el privado/ doméstico como el dominio de las mujeres.

Palabras clave: cosmopolítica; género; mujeres kichwa; chicha; Amazonía ecuatoriana 


\section{INTRODUÇÃ $0^{1}$}

Sarayaku (sara - milho, yaku - água, rio, portanto "rio de milho") é um povo runa (também kichwa ou quichua) que habita a região centro-sul da Amazônia equatoriana (el Oriente) (Figura 1), província de Pastaza (Figura 2), no curso médio do rio Bobonaza. Seu território, reconhecido pelo Estado equatoriano em 1992, abarca 135 mil hectares (Figura 3). É formado por sete centros ou comunidades (Sarayakillo, Shiwacucha, Chontayaku, Kali Kali, Mayka Llakta,
Kushillu Bara e Puma Bara), com um total de, aproximadamente, 1.300 habitantes. Pode-se chegar a Sarayaku por via fluvial em cerca de seis horas a partir de um porto em Canelos, ou por via aérea, viagem que leva aproximadamente 30 minutos.

Segundo Uzendoski \& Whitten (2014), os povos kichwas das terras baixas ou kichwas amazônicos encontram-se divididos em quatro grandes grupos sociais, sobrepostos às províncias na região amazônica equatoriana: Napo (Napo Runa ou

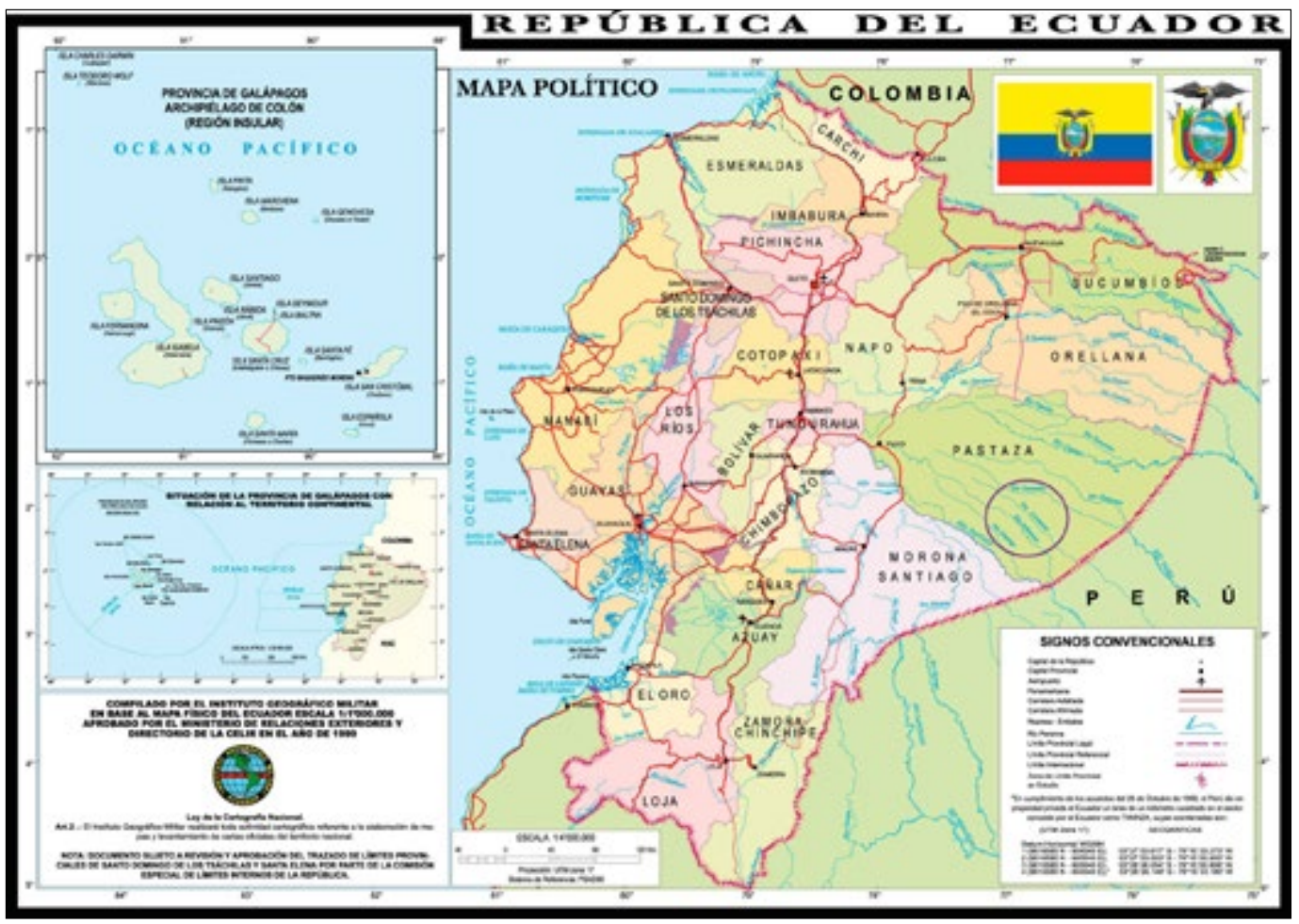

Figura 1 - Mapa do Equador (destaque para o rio Bobonaza). Fonte: Ecuadorec (2018).

1 Ao longo do texto, algumas palavras e frases são deixadas propositalmente em castelhano, em itálico, seguidas de sua tradução para o português. Algumas frases ou palavras que busco destacar em português também estão em itálico, bem como as palavras em kichwa ou outra língua. Todas as passagens citadas que estavam em outra língua foram traduzidas por mim. 


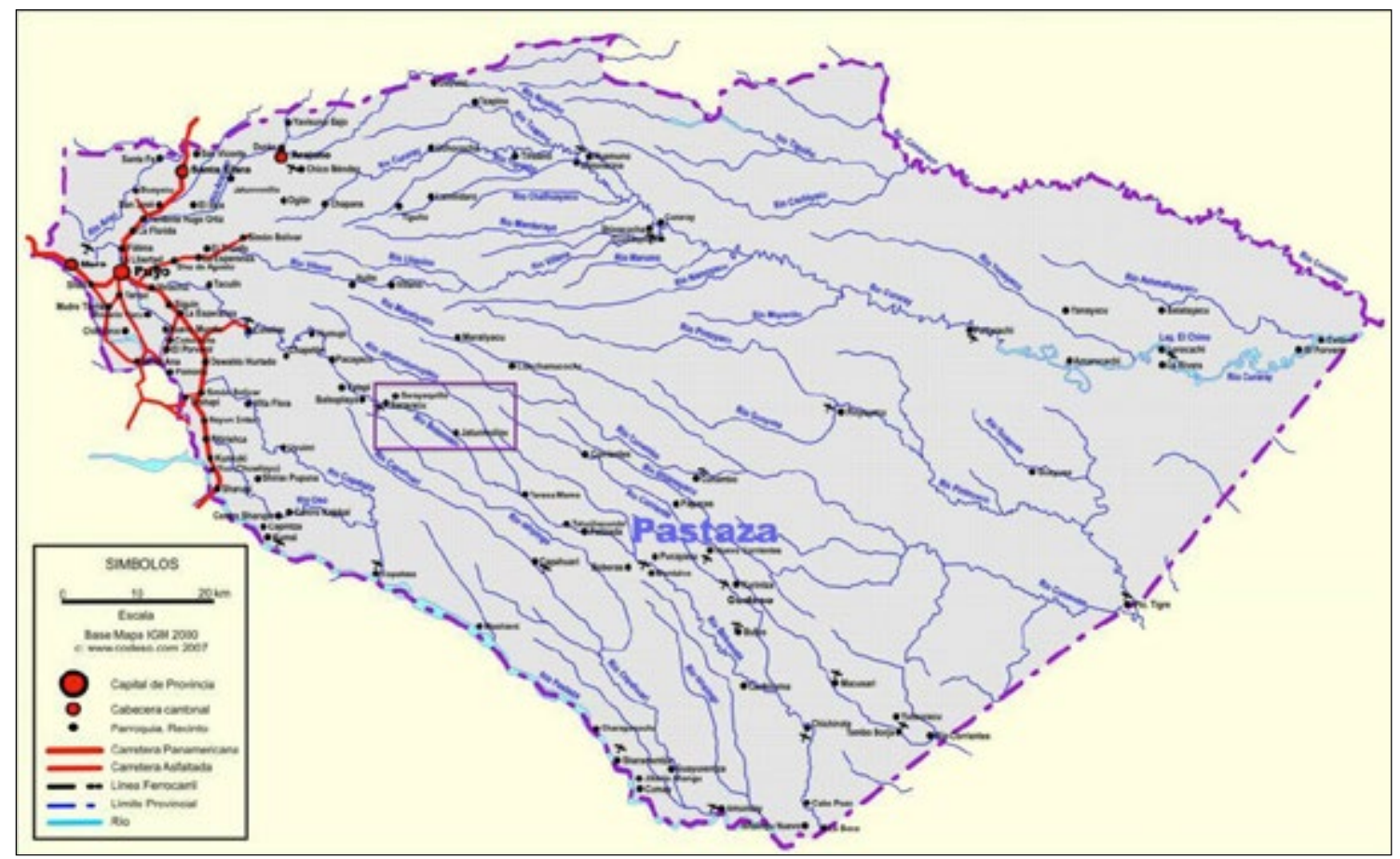

Figura 2 - Mapa da província de Pastaza (destaque para Sarayaku). Fonte: Codeso (2007).

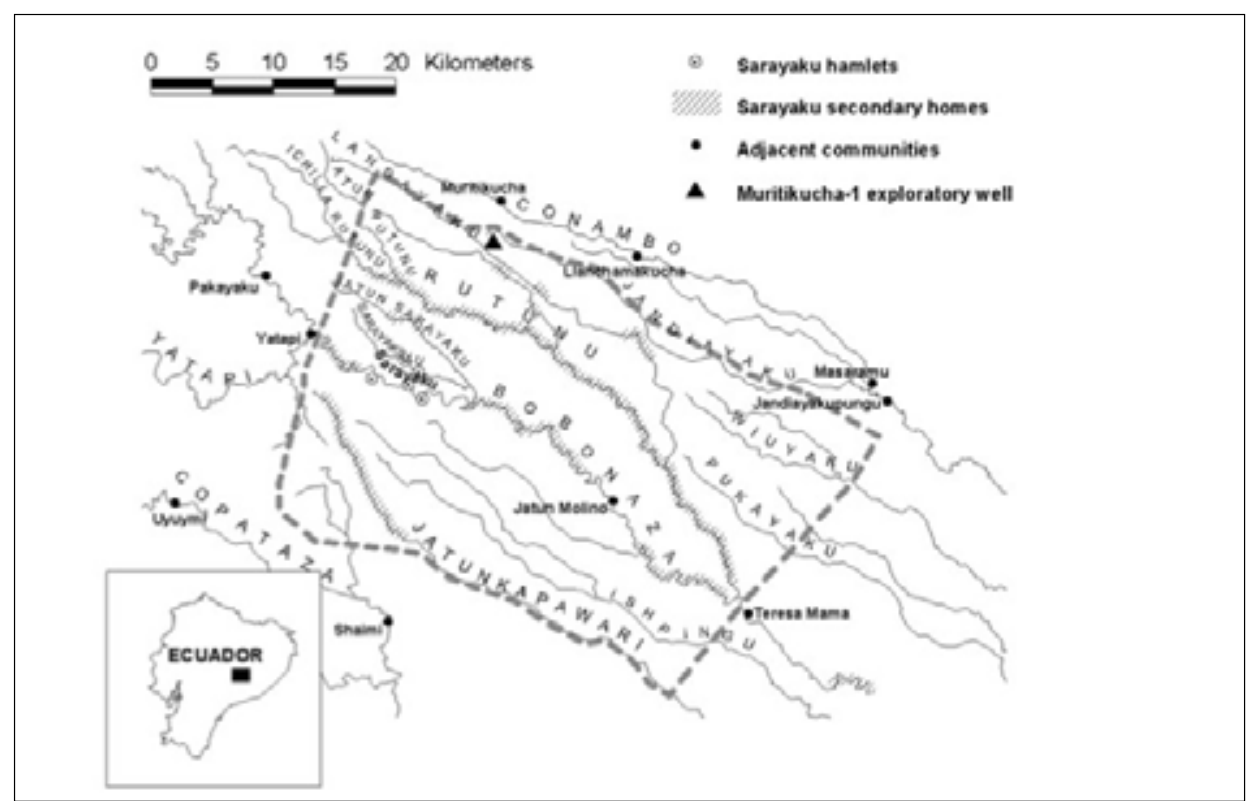

Figura 3 - Mapa do território de Sarayaku. Fonte: Siren (2014:38). 
Quichuas de Napo), Orellana (também Napo Runa ou Quichuas de Napo), Pastaza (Canelos Runa ou Canelos Quichua, Pastaza Runa) e Sucumbíos (Aguarico, Lago Agrio) $)^{2}$. Sarayaku pertenceria aos Canelos Runa, que são, por sua vez, subdivididos em pelo menos outros seis grupos: Puyo Runa, Canelos Runa, Pakayaku Runa, Sarayaku Runa, Montalvo Runa e Curaray Runa (Chávez et al. 2005). Entretanto, não utilizam este termo para referirem-se a si mesmos/as, autoidentificando-se como "Runaguna" (-guna é o sufixo que denota plural), "Sarayaku Runaguna" ou "Povo Autônomo Originário Kichwa de Sarayaku”. Ainda assim, os Canelos Runa são aqueles com os quais os/as Sarayaku Runa sentem mais afinidade, marcando suas características distintivas em relação, por exemplo, aos Napo Runa do norte da Amazônia equatoriana, bem como aos quichuas das terras altas andinas.

A língua dos povos kichwas amazônicos pertence à família linguística quéchua (também quichua ou kichwa), falada por milhões de pessoas distribuídas entre os territórios da Colômbia, do Peru, da Bolívia, do Equador e da Argentina. Na Amazônia equatoriana, as linguistas Orr \& Wrisley
(1981[1965]) e também Uzendoski \& Whitten (2014) identificam pelo menos três variações dialetais: Tena, Loreto-Ávila e Bobonaza-CurarayPuyo (as duas primeiras pertenceriam aos Napo Runa e a última, aos Canelos Runa). Sarayaku e outros povos kichwas da Amazônia, por sua vez, denominam sua língua de "Runa Shimi". Runa é uma palavra usada por Sarayaku e outros povos kichwas para referirem-se a si e a outras pessoas e grupos cuja língua materna é o kichwa, que significa "gente" e/ou "pessoa"'. Shimi, por sua vez, é traduzido literalmente como boca, mas também como voz, fala, língua e/ou linguagem - e Runa Shimi, "fala de gente", "linguagem de gente" (ou, em uma tradução mais simples, "língua kichwa").

Para além da classificação dos kichwas das terras baixas como "povos aculturados" ou "imigrantes dos Andes" 4 , tanto por parte da literatura etnológica e etnohistórica quanto da memória dos mais velhos, os povos kichwas da Amazônia e seus vizinhos (povos jivaroanos achuar e shuar, zápara e waorani) ocupam uma área ao longo dos rios Napo, Curaray e Bobonaza que, desde os tempos pré-hispânicos, foi parte de uma ampla esfera de interação regional não apenas com as terras

2 Ver também Whitten (1985), Whitten \& Whitten (2008), Reeve (2002), Uzendoski (2010) e Hudelson (1987).

3 Ver, além dos já citados, de la Cadena (2015) e Kohn (2013).

4 Para uma leitura crítica, ver, por exemplo, Gow (1993), Uzendoski \& Whitten (2014), Hudelson (1987) e Reeve (1988, 2014). 
altas andinas, mas também, e principalmente, com extensas parcelas da Amazônia para além de sua porção ocidental. Especificamente na região do território de Sarayaku, os povos kichwas teriam se formado a partir de casamentos interétnicos entre, principalmente, povos de língua jivaroana e zaparoana que adotaram o kichwa como língua franca - uma difusão fomentada pelos missionários nas terras baixas do Peru e do Equador no período colonial (a partir do século XVI), mas também, e talvez antes, uma adaptação própria destes e de outros povos aos efeitos devastadores da invasão europeia ${ }^{5}$.

O kichwa não é concebido, portanto, apenas como uma língua, mas também como um coletivo de pessoas - uma "cultura" ou, no contexto equatoriano, uma nacionalidade (indígena) formada por vários e distintos povos kichwas, tanto dos Andes quanto da Amazônia. É esta categoria de "nacionalidade indígena" que forma, contemporaneamente, as bases para a "plurinacionalidade" e, então, para o "Estado plurinacional", uma vez que, desde a Constituição de 2008, o Estado reconhece formalmente outras nacionalidades, para além da equatoriana, que buscam fazer parte desse mesmo Estado em seus próprios termos, em outras palavras, explorando as possibilidades de existir e transformar o Estado com formas de representação, territorialidade, justiça e autonomias indígenas ${ }^{6}$.

Líderes e lideresas ${ }^{7}$ (ou dirigentes/as) de Sarayaku foram e são pessoas ativas no interior de um movimento indígena (na figura de confederações de âmbito regional e nacional como a Confederación de las Nacionalidades Indígenas de la Amazonía Ecuatoriana, CONFENIAE, e a Confederación de las

5 Uzendoski \& Whitten (2014:2) apontam, por exemplo, que "no período colonial a cultura runa Amazônica se expandiu na região de Pastaza e Napo quando povos rivais como os shuar em relação aos andoa-shimigae-zápara e os zápara em relação aos waorani usaram o quichua para encobrir identidades rivais e suprimir hostilidades". Em parte da literatura antropológica, este processo é tido como uma "etnogênese" (Hill 1996). Por exemplo, Reeve (2014:16) - etnóloga que trabalhou com os Curaray Runa - menciona que "onde guerras, escravidão e epidemias dizimavam populações locais, a integração dos povos remanescentes em um sistema compartilhado e mais amplo através da exogamia etnolinguística é subjacente à etnogênese, pela qual uma nova identidade coletiva é assumida por povos anteriormente distintos". No entanto, Reeve (2014:14) também enfatiza, em diálogo com pesquisas arqueológicas, que "essa dinâmica social emergiu de tal forma - como etnogênese - mas seguiu padrões anteriores de interação entre povos amplamente distribuídos em áreas fluviais e interfluviais". Esta esfera de interação teria abrangido desde o alto Amazonas/Solimões e seus principais afluentes (os rios Napo, Ucayali, Marañón, Huallaga e o baixo Ucayali), as ligações desses rios que se estendiam para a região andina a oeste e por terra até a região do rio Negro, ao norte e a leste.

6 A categoria de nacionalidade indígena representou uma transição qualitativa em relação à de etnia, esta última percebida como uma inclusão subalternizada incapaz de deslocar o padrão referente branco-mestiço da nação equatoriana. Com a Constituição de 2008, dá-se o reconhecimento de quatorze nacionalidades indígenas (das quais pelo menos nove estão na Amazônia), formadas por um total de dezoito povos.

7 Em espanhol, utiliza-se o termo lideresas para designar líderes mulheres. Na língua portuguesa, parece não haver termo correspondente a este, então o mantenho no original, para destacar o efeito que esta palavra carrega no contexto em que trabalho. 
Nacionalidades Indígenas del Ecuador, CONAIE), e

foi a ação deste movimento que culminou, entre outros feitos, na inclusão da plurinacionalidade e de outros conceitos propriamente indígenas na Constituição do país (2008), na fundação de um partido político indígena, com ampla incidência na política institucional (o Pachakutiks, ainda na década de 1990), na elaboração de princípios que passaram a orientar (ainda que simbolicamente) a política econômica do Equador, como foi Sumak Kawsay/Bem Viver. Junto a outros povos da Amazônia equatoriana, há décadas, Sarayaku atua também na luta antiextrativista - especialmente petroleira -, tendo sido um dos únicos povos a ganhar um julgamento na Corte Interamericana de Direitos Humanos (CIDH) contra o Estado equatoriano9. Em suma, o povo de Sarayaku tem e teve uma participação decisiva não apenas em tornar explícita a "questão indígena" no/ao país, mas também em produzir entendimentos e experiências outras de existir sob um Estado.

Neste artigo, compartilho reflexões iniciais sobre a imbricação entre política, liderança, gênero e território entre as/os Sarayaku Runa, dedicando especial atenção ao ponto de vista, à atuação e à reflexão de algumas mulheres: Mirian Cisneros, a primeira mulher a efetivamente assumir a posição de presidência do Conselho de Governo Tayjasaruta ${ }^{10}$; Hilda Santi, a primeira mulher eleita para o cargo (pois logo saiu para presidir outra organização historicamente importantíssima, a Organización de los Pueblos Indígenas de Pastaza, OPIP); e Ena Santi, ex-lideresa de mulheres. Pergunto-me: o que é ser mulher e o que é ser

8 O Movimiento de Unidad Plurinacional Pachakutik - Nuevo País (MUPP-NP) é, grosso modo, um partido político criado pelo movimento indígena em 1995. É por vezes definido como o "braço político da CONAIE" ou uma "organização criada para garantir a participação indígena pela via democrática”, como me explicou certa vez Marlon Santi, atual coordenador nacional do movimento. No entanto, é preciso ter em mente que as origens e o objetivo deste movimento foram (e têm sido) o de agrupar toda a expressão social e política que se opõe ao neoliberalismo, buscando constituir-se como uma organização representativa de muitos e distintos grupos populares que não apenas os povos indígenas do país ou, no pior dos casos, restringindo-se a uma "agenda étnico-cultural". Para uma análise detalhada sobre a história do Pachakutik, ver, por exemplo, Marc Becker (2015).

9 No julgamento do caso Povo Indígena Kichwa de Sarayaku vs. Equador (2012) pela Corte Interamericana de Direitos Humanos (CIDH), o governo equatoriano foi culpabilizado por ter concedido a outorga para exploração petrolífera e de hidrocarbonetos, com o uso de material explosivo, a uma empresa privada (CGC) no entorno e em parte do território de Sarayaku, sem o consentimento do povo. O empreendimento ocasionou, entre outros danos, contaminação do solo e das águas e ameaças contra líderes, ensejando a reparação.

10 Tayjasaruta é um acrônimo que nomeia o Conselho de Governo de Sarayaku. A tradução que me foi feita é a seguinte: "ta" de tayak, antigos, antepassados, ancestrais, ou os primeiros homens e mulheres do povo kichwa de Sarayaku; "y" de yuyayta, conhecimento, sabedoria e força espiritual; "ja” de jatachi, aquele que se levanta para construir o caminho da identidade cultural; "sa" de Sarayaku; "ru" de runaguna, traduzido como pessoas com ética e princípios da cultura; "ta" de Tandanakuy, forte unidade pela defesa dos direitos dos povos indígenas. Deste Conselho de Governo, participam formalmente técnicos, kurakas, líderes e lideresas. As reuniões são abertas ao povo e geralmente acontecem na Casa del Mediodía. 
lideresa? O que é ou pode vir a ser um território e qual sua relação com as mulheres? Que política fazem as mulheres, ou como territorializam o mundo e a política? De que forma produzem espaços particulares de coexistência aos modos outros, incluindo os não indígenas (ahuallacta $)^{11}$, de fazer mundos? Meu ponto de partida é quase inteiramente baseado em material etnográfico decorrente de meus trabalhos de campo ${ }^{12}$; ainda assim, busco evidenciar as conexões (iniciais e parciais) com outros trabalhos que informam os problemas aqui discutidos.

Se este artigo presta atenção especial ao ponto de vista de algumas mulheres, o faz a partir de um duplo estímulo: (1) contribuir para uma visibilização das mulheres, por vezes deixadas de fora das etnografias como interlocutoras (Rosaldo \& Lamphere 1974; Overing 1986; McCallum 1999, 2001); (2) dedicar atenção ao interesse de meus/ minhas interlocutores/as, uma vez que "a questão das mulheres" é um tema de reflexão constante entre os/as Sarayaku Runa, e uma pesquisa com e sobre mulheres tem sido considerada como "bemvinda”. No entanto, logo de início aprendi que isto significa não falar exclusivamente com as mulheres ou sobre "as mulheres"; nos eventos e situações que presenciei, a "questão das mulheres" é debatida por todos/as e, mais importante, colocada pelas mulheres como "algo" que não diz respeito somente a elas. Assim, se não faria sentido falar "apenas com/sobre as mulheres" e lideresas, parece-me que o que, sim, faz sentido é olhar, neste artigo, para a criatividade dessas mulheres, buscando pensar como se constituem enquanto lideresas, sinzhi warmiguna (mulheres fortes), mas também - e sobretudo - como uma modalidade de sinzhi runa (pessoa forte) $)^{13}$.

\section{NOTAS SOBRE O TRABALHO DE CAMPO}

Durante meus períodos de campo, sou recebida na casa da atual presidenta, Mirian, minha amiga e parceira de pesquisa. Em Sarayaku, a casa de Mirian e seu marido, Marlon, está próxima a casa de seu cunhado, Daniel, em terreno que foi

11 Literalmente, povo ou pessoas das terras altas (ahua, que significa "acima", "alto"). Até onde pude entender, o termo designa mestiços, brancos, mas não a população indígena que habita os Andes.

12 Os trabalhos de campo foram motivados por minha pesquisa de mestrado (Ghirotto 2015) e, posteriormente, em razão de minha pesquisa de doutorado (em andamento). No mestrado, o trabalho de campo foi realizado de setembro a dezembro de 2014; no doutorado, os períodos de campo aos quais me refiro neste artigo foram realizados entre março e abril de 2018; julho a outubro de 2018; e agosto a outubro de 2019.

13 Segundo as linguistas Orr \& Wrisley (1981[1965]), a grafia adequada seria huarmi. Porém, mantenho a forma warmi, mais comumente utilizada por meus/minhas interlocutores/as. De forma semelhante, outra grafia para sinzhi seria sinchi, mas opto por manter a primeira. Uma outra tradução para sinzhi, neste contexto, poderia ser "conhecedor/a" ou, ainda, "valente". 
anteriormente da já falecida Beatriz Gualinga, uma importante líder e mãe dos dois. Aqui, tratarei de meus períodos na casa de Daniel, pois, até então, Mirian não tinha construído sua própria casa. A casa de Daniel fica bem em frente ao pátio ou praça central e próxima à Casa del Mediodía, principal espaço para reuniões; à Guayusa Net; ao posto de saúde; a uma das escolas; a uma quadra de esportes. Portanto, além de ser o lugar onde residem esta e outras famílias/parentes (ayllu), é também o lugar onde as pessoas se encontram para reuniões, festas etc., que envolvem o povo (llacta) como um todo.

Por estar localizada na região considerada como central do território de Sarayaku, e por ser a casa da atual presidenta e de Marlon, expresidente de Sarayaku e outra liderança bastante importante para este povo e para o movimento indígena (atualmente, é coordenador nacional do Pachakutik), é uma casa que recebe muitas visitas. Estas visitas não são exclusivamente de familiares, mas também "políticas", "de organização", como explicou-me Mirian. São discutidos os mais diversos assuntos: o futuro do povo, os problemas com o Estado, transporte nas canoas, próximas reuniões, conflitos, comentários sobre a vida de amigos e familiares próximos, questões de saúde, atualização sobre o que havia acontecido afuera (fora do território, nas cidades) etc. Mas são também momentos de risadas - proferidas em alto e bom tom, principalmente pelas mulheres -, festas, tragos (bebidas), contos, piadas. A observação de Perrone-Moisés (2015) de que todos os caminhos levam ao pátio principal não poderia ser, neste caso, mais literal.

A co-habitação com esta família me impôs um marcador mais ou menos particular, se comparado a outros antropólogos que também trabalham em Sarayaku: eu estava hospedada na casa da presidenta e era constantemente vista por quem passava pela praça central ou parava para visitar. Mas, certamente, o fato de estar hospedada na casa de pessoas com certo prestígio não foi o único marcador com o qual me vi distinguida. Sou uma mulher cis, branca, mais ou menos fraca para trabalhos que envolvem alguma força - como a chagra (roçado, áreas cultivadas), carregar mandioca (lumu, em kichwa, ou yuka, em castelhano) -, sem fluência em kichwa e brasileira - uma nacionalidade que rende pouquíssima proximidade simbólica entre eu e eles/as, embora gere alguma curiosidade passageira.

Mas o que gostaria de explicitar é que, como mulher, eu tive que seguir um caminho mais ou menos específico de conhecimento se quisesse aprender alguma coisa sobre "a cultura" e "a política" runa - esta última, tema de minha pesquisa de doutorado em andamento. Estes e outros marcadores circunscrevem minha atuação 
e fazem emergir demandas em relação à minha pessoa, bem como me impeliram a executar determinadas atividades ou a me comportar de uma forma específica, que não são as mesmas caso eu fosse homem - ou efetivamente não são as mesmas de meus colegas de atuação. Mas o reconhecimento de que o gênero influencia o que se pode ou se deve aprender não é mera autorreflexividade complacente, como já previram, entre outras etnográfas, Mezzenzana (2015), em seu trabalho também com os Pastaza Runa, e McCallum (1999, 2001, 2009), ao relatar a forma pela qual os Nawa, categorizados como "amigos/as" do povo Huni Kuin, são incentivados a viver de acordo com um tipo ideal de pessoa genderizada/generificada (gendered personhood), aprendendo e realizando as múltiplas atividades que criam o gênero adequado, segundo esta pesquisadora. Tal admissão diz respeito, portanto, ao fato de que o que aprendemos no campo depende tanto de nossos próprios motivos e pressupostos quanto daqueles das pessoas com as quais trabalhamos, ou seja, de (pelo menos) uma relação. Ainda assim, explicitar estas questões me parece um tanto paradoxal porque também coloca o "problema" do "gênero feminino" como o lugar marcado, afinal, muitos trabalhos com povos amazônicos sobre, por exemplo, xamanismo, guerra e caça - atividades prototipicamente masculinas - nem sempre mencionam o gênero (Mezzenzana 2015, 2014). Existiria um conhecimento sem gênero? O "conhecimento de gênero" significa que algum conhecimento só pode ser acessado por mulheres ou homens? Quais as consequências disto para a antropologia e o trabalho antropológico? Estas são algumas questões que permeiam este artigo, embora não sejam o foco principal dele.

\section{LIDERANÇA E POLÍTICA, OU SOBRE CONHECIMENTO E IMPORTANTES CONVERSATÓRIOS}

Quando perguntei a alguns amigos/as como se dizia "política" em kichwa, obtive como resposta um apertar de olhos, expressão de dúvida, um murmurar de palavras. Silêncio. "Não tem; é uma palavra muito técnica, muito ocidental", disse, por exemplo, Marlon. Depois de alguns inquéritos consigo mesmo, falou: "hatun kuyntanakuy", ou "algo como 'grande reunião de conversatório'”. Daniel, também depois de muito pensar, respondeu - e escreveu em meu caderno - "hatun yuyaykuna[guna] kwintanakuy". Yuyaguna foi traduzido como conhecimentos, mas disse-me que o termo yuyayguna também poderia ser traduzido literalmente como política. Hatun seria grande 
e/ou importante, e kwintanakuy seria dialogar, conversar ou, ainda, um conversatório. Política como conhecimento ou algo como uma grande e/ ou importante reunião, conversatório, conversa, diálogo $0^{14}$.

Buscando perseguir essa tradução de política, tenho olhado para alguns desses conversatórios puxados por líderes e lideresas. É dizer, lideranças seriam aquelas pessoas que (entre outras "coisas") fazem diálogos, conversatórios ou, ampliando um pouco mais, "fazem a fala" (ou uma modalidade de fala $)^{15}$. Se entendi bem, a expressão hatun yuyayguna kwintanakuy parece instaurar, de um lado, uma diferença em relação a algumas das conversas mais informais, que são estabelecidas na rotina. Parece-me que essa distinção inclui - além de outros aspectos que não poderei mencionar aqui - as diferentes formas expressivas usadas em um e outro contexto: uma fala forte, dura, de enfrentamento, como geralmente é quando há brancos, mestiços e/ou não indígenas ou quando o tema suscita polêmica; uma fala conciliadora, branda, "fazedora de paz", frequentemente quando uma liderança $f a z$ um conversatório no território; um aconselhamento (público ou privado); uma contação de "história" ou "lenda" (o que nós chamamos de mito) etc.

De outro lado, além de olhar para estes atos de "fazer a fala" ou de "fazer o diálogo/conversa", aqui busco dedicar atenção a algumas reflexões de minhas interlocutoras feitas em momentos informais, é dizer, não em conversatórios formais, mas sobre esses conversatórios formais - ou sobre estar lideresa -, bem como observações minhas enquanto as presenciei liderando um conversatório "formal" ou realizando outras atividades. Como veremos, me parece que estas falas apontam com mais ênfase para a "outra perspectiva" da tradução de política: a de conhecimento. É particularmente interessante dedicar atenção ao conhecimento, ou às possibilidades de ser e mostrar-se como conhecedora, justamente porque esta parece não se restringir, ou não sustentar, a dicotomia formal/ informal, cotidiano/excepcional - estas últimas, dicotomias que eu mesma não deixo de enxergar ao perseguir a tradução do termo política. De toda

14 Se dizemos "política" em castelhano, a conversa envereda rapidamente pelas lutas no âmbito do Pachakutik, travadas contra o Estado e empresas, por direitos etc., mas o mesmo não acontece de forma tão direta quando perguntamos a tradução em kichwa. Como bem notou Sztutman (2018:14), em "A queda do céu”, Kopenawa \& Albert (2015) mantiveram muitas vezes a palavra "política" em português com asterisco, pois esta parece intraduzível ao idioma yanomami. Como escreve Perrone-Moisés (2015), o termo "política" em português é empregado não raro para designar a "nossa política", sendo intransferível para relações propriamente indígenas. De todo modo, pontua Sztutman (2018), continua cabendo aos/às antropólogos/as - e, reversamente, também aos indígenas - a busca de traduções menos ou mais exatas, isto é, o controle das "equivocações", para voltar a uma expressão de Viveiros de Castro (2004).

15 O que nos conduz ao lastro entre política e palavra, já vislumbrado por autores como Robert Lowie e Pierre Clastres. Ver Sztutman (2018:14). 
forma, o que pretendo sugerir é que ser lideresa é uma forma constante de produzir-se e de mostrarse enquanto uma pessoa conhecedora, verdadeira ou adequadamente runa, capaz de levar o coletivo adiante da forma correta (a forma boa de se viver), e o gênero parece ter implicações importantes sobre isso.

Minhas/Meus interlocutoras/es identificam (pelo menos) duas modalidades ou planos de liderança. A primeira seria observada em posições "formais", como as de kuraka16 (um "líder tradicional", como me explicaram) e de dirigentes do Conselho de Governo Tayjasaruta - este último caracterizado como um "regime misto, isto é, tradicional e ocidental". Embora ambas as posições sejam distintas entre si, são tidas muitas vezes como um trabalho (tarabana) exercido por um período de tempo específico. Além disso, as pessoas que estão ocupando a posição de presidência e/ou kuraka são facilmente identificáveis: ambas utilizam, durante os conversatórios ou em outras ocasiões, um "bastão de mando" ${ }^{17}$.

A outra modalidade de liderança seria percebida nas figuras dos yachak ${ }^{18}$, apamamaguna (avós), apayayaguna (avôs) ou simplesmente ancianos/as (os "mais velhos") - pessoas que se tornaram conhecedoras e sinzhi (fortes), que detêm "os conhecimentos", que aconselham, auxiliam, orientam e inspiram as lideranças formais e as demais pessoas - cada uma à sua maneira. Este é um ponto importante, pois, quando perguntei o que significava ser líder/ lideresa ou o que era preciso para ser líder/ lideresa, me disseram que era justamente uma pessoa bem forte, bela, capaz de fazer uma boa fala e de levar adiante as pessoas, "andar de botas" e estar com o povo, trabalhando a terra, participando das mingas (trabalho coletivo em troca de comida e bebida, também chamado de festa), pescando, mantendo uma chagra (roçado, áreas cultivadas) bem bonita, cuidada e livre

16 Atualmente, o kuraka deve ser idealmente um homem maduro e casado, mas não necessariamente um yachak. Ele atua na resolução de problemas em seu setor, como brigas entre jovens ou entre marido e mulher, principalmente aconselhando as pessoas; organiza sua comunidade para a realização das mingas (trabalho coletivo em troca de comida e chicha, também chamado de festa); comunica e convoca reuniões importantes; participa no Conselho de Governo Tayjasaruta e informa seu setor sobre as decisões tomadas, mas ele mesmo não pode tomar decisões que envolvam o povo como um todo. É fundamental, portanto, saber mediar (conflitos), convocar e liderar. Igualmente importante é que alguma mulher (afim ou consanguínea) possa oferecer chicha nas mingas por ele convocadas.

17 A história deste bastão remonta ao período de colonização espanhola e dominicana, mas foi reapropriada pelos/as Sarayaku Runa. Ver Chávez et al. (2005).

18 A palavra yachak significa literalmente "aquele que sabe" ou "aquele que tem conhecimento". Em Sarayaku, o xamã é yachak, mas nem todos os yachaks são xamãs (que viajam para outros mundos pela ingestão de ayahuasca, por exemplo). De qualquer forma, me foi dito que "xamã” é uma palavra ocidental e que a tradução mais apropriada seria, de fato, yachak. 
de ervas daninhas, produzindo boa mandioca e chicha (ou aswa/asua, em kichwa, a cerveja de mandioca) da forma correta, ser "fazedora de paz", ao mesmo tempo em que é capaz de se tornar brava e feroz quando preciso - como efetivamente foi durante a guerra com as empresas petroleiras.

Meu ponto tem sido, então, o de dedicar atenção às falas, atuações e criatividades destas três mulheres que estão ou estiveram lideresas, puxadoras de conversatórios, e sua conexão com uma das formas pelas quais mostram-se conhecedoras (e mantêm-se não apenas como lideresas, mas também como uma mulher propriamente runa): a chagra e a mandioca transformada em chicha, ambas importantíssimas, sugiro, para a política traduzida como conhecimento e/ou conversatório. Parece emergir, a partir destas mulheres, muitas "coisas" - incluindo teorias sobre a ação política e a potência da fala -, mas, aqui, gostaria de evidenciar uma teoria ou propor uma ficção persuasiva, para usar uma expressão de Strathern $(2004,2006)$ do que fazem as mulheres no duplo sentido do termo (isto é, "do que as fazem mulheres" e "do que fazem as mulheres") e "o feminino", que parece configurar um modo de atuar no mundo, de fazer mundo e, portanto, de fazer (cosmo)política.

\section{SOBRE PESSOAS FORTES: HISTÓRIAS DE MULHERES}

\subsection{HILDA SANTI}

Hilda Santi é atualmente lideresa de educação. Ela conta que começou a liderar desde muito jovem. Sua primeira experiência foi como dirigente de mulheres na Organización de los Pueblos Indígenas de Pastaza(OPIP), em 1992. Tinha 25 anos e "não tinha conhecimento". "As mulheres se sentiam mal, só eram mães e esposas e não chegavam a ser líderes de nenhuma organização. Por isso, começaram a reivindicar estes direitos como mulheres e a ocupar outro espaço no território", contou-me. O tempo passou e Hilda foi escolhida como vice-presidenta de Sarayaku, no mandato de Franco Viteri. Foi neste período, entretanto, que Sarayaku enfrentou novamente um conflito com uma empresa petroleira, e Franco teve que ficar mais tempo na cidade. Assim, Hilda assumiu a organização e "teve a chance de liderar as pessoas adentro", nas linhas (literalmente) de frente do conflito - os limites do território por onde entrava a empresa.

Em 2005, foi eleita presidenta de Sarayaku, a primeira mulher a assumir a posição. Neste momento, Sarayaku já estava na Corte Interamericana de Direitos Humanos (CIDH) e ela chega até Washington. Hilda conta que este era um cargo muito duro e que não se sentia preparada, mas ela era forte e conhecida nas comunidades. Nesse momento, pontua Hilda, havia novamente muitos conflitos internos porque "muita 
gente ainda pensava que a empresa [petroleira] dava dinheiro, e eram as mulheres quem diziam 'não vamos permitir"'. "Mas por que as mulheres?", perguntei. Para Hilda, quando os homens começam a ganhar dinheiro não fazem bons investimentos. "Tudo isso já havíamos sofrido, a entrada das petroleiras não nos traz beneficios. Franco apoiou 100 por cento nossa proposta, enquanto outros diziam que não devíamos opinar em nada”.

Hilda esteve seis meses liderando, mas teve que sair porque ocorreu uma divisão na OPIP - "alguns viraram governistas e outros ficaram a favor da organização" -, e ela havia sido chamada para presidiresta organização. Hilda ainda não se sentia preparada, "não dominava palavras técnicas", mas "obedeceu ao mandato dos povos". Passados oito meses, a OPIP seguia com sérios problemas; seus filhos estavam sozinhos em Sarayaku e Hilda "só passava na cidade". "É melhor eu ir", contou. Depois, escolheram-na para o cargo de Teniente Politico ${ }^{19}$, novamente a primeira mulher a assumir esta posição em Sarayaku. "Sempre quiseram me manipular, mas nunca conseguiram. Diziam 'ela é uma mulher bem forte e séria, não tem como negociar com ela. Poucas mulheres conseguiram estar nisso" (grifo meu). Segundo Hilda,
As mulheres kichwas devem ter cabelo negro e rosto pintado, pois essa é a nossa identidade. Essa energia transmitimos de geração em geração, outros povos não são assim de manter essa comunicação. Nisso estamos nós, as mulheres. Os

espíritos que conheci, como a mulher Huituj [Genipa Americana] - uma mulher que se convertia em fruta -, tudo isso mantemos para manter o território. Isso valorizamos.

Transcrevo, ainda, outro trecho de uma fala de Hilda:

Então sempre trabalhamos assim, a tarefa das mulheres é bem dura. Meu primeiro esposo me tratava muito mal porque eu era a primeira dirigente. Ele não compreendia nada. Melhor caminhar sozinha do que mal acompanhada. Eu fui muito criticada porque eu deixei muito cedo meu marido. Depois disso eu tive dois namorados. Mas nunca abandonei meus filhos e sempre lutei pelo meu povo. Isso ninguém pode falar; eu nunca deixei de lutar. [...] eu nunca vou deixar de lutar pelo meu povo. Trabalhamos bem coordenado. Aqui as pessoas estão bem organizadas. As irmãs da igreja ajudavam com comida para as crianças quando as mulheres estavam nas fronteiras; as crianças ficaram sozinhas por seis meses quando a empresa chegou, ou seja, todos trabalhamos, o trabalho sempre foi coletivo. Muita gente me critica por minha debilidade dentro do romance, do pessoal. Eu me separei. Mas no âmbito da luta eu sigo firme. Embora eu tenha três passados, no âmbito da luta eu sigo forte e por isso seguem me valorizando. Nunca traí roubando ou abandonando nossa organização, dividindo, por isso me valorizam. Por isso, as mulheres também me reconhecem, na vida organizativa eu sou coerente. Então isso é a valentia, que sejamos justas na organização, não se pode trair os princípios organizadores, não devemos ser invejosas, mentirosas. Eu cumpri essas normas. Muitos deixam a dirigência [posições de liderança, 'vida organizativa'] e se vão. Mesmo que não me convidem eu vou. Porque também ninguém me disse para não ir. Eu, de minha parte, sou assim. Não quero me trancar na casa. Eu me organizo.

19 Representante da paróquia rural. O Equador se divide política e administrativamente em 24 províncias que, por sua vez, estão subdivididas em 219 cantões. Os cantões estão divididos em paróquias urbanas ou rurais. 


\subsection{ENA SANTI}

Hilda Santi é tia de Ena Santi, ex-lideresa de mulheres de Sarayaku. Ena tem doze filhos. Hilda conta - e eu também presenciei durante meu trabalho de campo - que Ena foi criticada inúmeras vezes porque não tinha marido (é viúva há alguns anos) e não tinha com quem deixar os filhos. Eles ficavam sozinhos em Sarayaku, principalmente quando ela virou dirigenta de mulheres. "Estava com vergonha porque todos estão falando que as mulheres vão ser como a Ena... Mas isso eu não deixo, os homens também são iguais! Ela não engravidou sozinha. Eu gosto de ser solidária”, me disse Hilda.

Quando conheci Ena, em 2014, ela ainda era lideresa de mulheres de Sarayaku. Naquele tempo, comentou que para ser dirigenta:

É preciso ser uma mulher líder, que
tenha capacidade de poder levar as
mulheres adiante, porque sempre
é preciso ser um pouco preparada,
são muitas as funções das mulheres
dirigentes. Antes as mulheres eram
eleitas como lideresas mas não iam a
nenhum lado, só passavam metidas
aqui, mas nós mulheres estamos
aparecendo pouco a pouco. Nos
convidam. Mas para isso é preciso
planejar, organizar, porque é preciso
organizar a dirigência e também
a família porque eu não posso
simplesmente sair e deixar meus filhos.
Ou seja, uma mãe precisa se organizar
porque há muitos trabalhos, muitos
trabalhos para as mulheres dirigentes ${ }^{20}$.

Já em março de 2018, reencontrei Ena. Depois de deixar a posição de liderança, disse-me que seguiu aplicando oficinas sobre o tema de mulheres em outras comunidades. Também comentou que não era uma mulher de ficar em casa; ela sempre saía cedo para ir à chagra e trabalhava bem duro. Minha percepção foi de que Ena havia mudado muito. Foi, então, que ela me contou sobre como antes, quando foi eleita como líder, "não sabia falar": tinha vergonha, medo, tremia, as ideias fugiam da cabeça, não conseguia olhar nos olhos, se sentia desconfortável em ter de falar em castelhano. Mas isso não a fez recuar, como se poderia fazer pensar - afinal, a vergonha e o silêncio podem fazer parte da fala, do diálogo e/ou da política, para manter a proposta de tradução. Mas não olhar nos olhos das pessoas era uma forma de negá-las, disse-me Ena. Então ela aprendeu a falar forte, a falar bonito. E, se aprendeu, ninguém tiraria isso dela. Seguiria "alzando la voz" (levantando a voz, fazendo-se ouvida).

Ela também me contou, certa vez, sobre as formas de comunicação que as mulheres empreendem. Disse que quando vivia com sua avó, ela sempre madrugava para ir à chagra. Ao chegar gritava, e outra mulher - em outra chagra - gritava também. Para Ena, essas mulheres eram "mulheres bem fortes" (grifo meu); "essa era a comunicação, a forma de pensar, pelo grito". Mas, além do grito,

20 Em entrevista realizada em novembro de 2014 por mim, Maria Luiza de Castro Muniz e Carmen Seco Pérez. 
"essas mulheres também sabiam rir", "e com o sentimento que uma pessoa tem, imitavam os pássaros. A risada tem sentido dos animais, e minha avó sempre fazia essas coisas, essa é uma comunicação das mulheres”.

\subsection{MIRIAN CISNEROS}

Mirian Cisneros é a atual presidenta de Tayjasaruta, do povo kichwa de Sarayaku. Mesmo convivendo com um sério problema de saúde, mantém uma rotina de trabalho - e de "grandes conversatórios" - extremamente cheia. Para sua surpresa (não havia lançado candidatura), foi eleita pela Assembleia Geral como presidenta de Sarayaku para o período 2016-2019, a primeira mulher a assumir a posição por todo o mandato, desde que Sarayaku começou a se "organizar sob esta estrutura mais ocidental", o Conselho de Governo, tal como me disse.

Domingo de manhã, em Sarayaku. Mirian levanta cedo, ainda é noite. Cozinha o café da manhã, serve os pratos, lava a louça. Veste a chamada "roupa tradicional", desta vez de cor azulescuro, com mangas até os cotovelos e pequenos detalhes em vermelho e amarelo que adornam as extremidades. Coloca brincos e pulseiras feitos por mulheres kichwas, pega seu bastão, atravessa a praça central e chega na Casa del Mediodía. Cerca de 40 mulheres e algumas crianças lhe esperavam; era o dia da "reunião de mulheres".

Ao passar por cada ponto que ia sendo apresentado por Andrea, sua secretária, Mirian fazia uma fala introdutória e as mulheres presentes se manifestavam. Como nos demais conversatórios que acontecem "adentro" (em Sarayaku), Mirian cumpre quase todo o tempo um papel de mediadora e "fazedora de paz" (Perrone-Moisés 2015:40) abrir e encerrar a reunião, introduzir um assunto, fazer observações ou aclarações pontuais, proferir aconselhamentos - afinal, "liderar é diferente de dominar", como me explicou. Mas quando a reunião é fora e envolve não indígenas, o que prevalece é, geralmente, o tom de enfrentamento.

No final do dia, retornamos à casa para cozinhar o jantar. Mirian me conta sobre o papel de sua sogra, Beatriz, a primeira mulher a se tornar liderança e a lutar por "questões das mulheres". Mirian comenta, neste e em outros momentos, como é duro ser presidenta $e$ mulher, pois exige a realização de muitas funções. "Os homens têm que estar sempre limpos e bem alimentados, enquanto as mulheres não descansam nunca. Além disso, como presidenta, eu não consigo ter a minha chagra e nem fazer minha chicha". Este comentário sugere uma dificuldade que ela (e muitas outras pessoas) manifestam em relação à posição de liderança, e que não se resume apenas às mulheres: me refiro ao fato de ser casada/o, 
seja homem ou mulher, uma vez que passar um tempo considerável fora de Sarayaku gera muitas tensões no interior da casa (huasi).

Neste momento, chegam em sua casa muitos homens. Um deles me pergunta se sou feminista. Diz que ele não gosta da ideia de as mulheres quererem se igualar aos homens porque existem muitos homens maus. Por que iriam querer ser tão ruins quanto eles? Sem saber muito bem o que responder, tentei me esquivar da conversa. Depois que os homens se retiraram da casa, o cunhado de Mirian - Daniel - me pergunta o que o homem tinha me perguntado. E começa a me contar sobre as diferenças fundamentais tal como os/as Sarayaku Runa as entendem: enquanto a mulher está para a chagra, a chicha, as cerâmicas, os homens estão relacionados à selva e à caça, são sacha runa (gente da selva). Além disso, "os yachaks já falavam que a Pachamama é tudo, e que ela é mulher, uma mulher engrandecida, e por isso não há machismo entre nós”.

Meses depois nos despertamos para mais uma reunião no período da manhã, na Casa del Mediodía. Havia também aproximadamente 40 pessoas e uma longa agenda de discussão. Um casal estava sentado diante das mesas ocupadas por dirigentes/as e kurakas, destacando-se das demais pessoas que participariam da reunião. A mulher, bastante brava, começa a relatar ininterruptamente os maus tratos que estava sofrendo de seu marido.

Ele bebia e "le pegaba" (lhe batia), mas aquilo era um gesto de basta: caso se repetisse, ela deixaria a casa e iria embora. O homem permaneceu calado. Era uma longa discussão sobre violência no âmbito doméstico-familiar que se transladava ao Conselho de Governo.

Hilda "les habla duro" (fala forte, com firmeza), sobretudo ao homem. Este tipo de atitude não era permitido, além de ser feio, e ele deveria comportar-se como um bom homem. Depois foi a vez de Mirian, que falou sobre ele ser kuraka e mais velho que ela, de forma que aquela era uma situação extremamente incômoda. Ela não deveria estar dando conselhos a ele, e sim ele a ela. O casal ouviu atentamente os aconselhamentos proferidos pelas lideresas e, após terminarem, voltaram-se aos bancos onde estavam os demais presentes. A reunião prosseguiu.

Após seu término, cozinhamos o almoço e lavamos as louças. Mirian e sua cunhada (esposa de Daniel) logo se levantam para ir à chagra. Botas, facões, calças compridas, ashanga (cesto de fibras naturais). "Vou pegar mandioca, porque uma presidenta sem chicha... Vão dizer que ela é preguiçosa. Por isso tenho que fazer”, comenta Mirian. Neste momento, ela já tinha duas chagras que familiares (homens e mulheres) ajudavam a cultivar: uma delas, um enorme terreno que 
se alcança com uma caminhada de cerca de 30 minutos pela via Kali Kali; e a outra baixando (uraita) o rio Bobonaza, a cerca de 20 minutos de canoa, bem perto da beira do rio. Foi desta segunda que tiramos a mandioca; é uma chagra que foi anteriormente da mãe de Marlon e Daniel, sua sogra, e hoje é cultivada por Mirian. Nos dias que se seguiram, muitas mulheres passaram por sua casa para emprestar baldes de plástico, descascar mandioca, ajudar no cozimento e, finalmente, macerar e mascar a mandioca para fazer chicha. Mas uma delas ficou: era a kurakamama de Kali Kali; seu marido, o então kuraka, era o responsável por organizar a delegação de Sarayaku para o XV Congresso da Nacionalidade Kichwa de Pastaza, que iria acontecer em Canelos, em agosto de 2018. Parte da chicha, portanto, seria servida na casa de Mirian, mas também seria levada para o Congresso. Lá eles tinham que "fazer bonito" e brindar (oferecer) muita chicha para os parentes.

\section{CHAGRA E CHICHA}

Gostaria de olhar mais detidamente para a importância que essas mulheres dedicam a conhecer, a falar bem, a organizar-se, a prepararse, a lutar, enfim, a mostrarem-se como uma pessoa propriamente runa - de forma ainda mais decisiva quando pensamos as posições de liderança formal.
Especificamente, a qualidade de sinzhi (forte) é enfatizada, e esta parece ser referida tanto a uma resistência física excepcional quanto a um corpo de conhecimento bem fundamentado (e a manutenção de tal separação é mais minha do que de meus/minhas interlocutores/as). Mas foime explicado que ambas as capacidades também estariam conectadas à "força de vida" que uma pessoa pode ter. Esta força é frequentemente referida como samai - também relacionado com a possibilidade de atuar, de ser saudável e de resistir, seja carregando algo pesado, cultivando uma bonita chagra, produzindo e oferecendo boa chicha em uma linda mocawa $a^{21}$, em pescar ou ir caçar no bosque, em fazer uma boa fala.

A tradução do termo samai, bem como suas formas de transmissão (geralmente pelo sopro), fortalecimento e enfraquecimento, é bastante complexa. Aqui, limitar-me-ei a sinalizar apenas algumas tentativas de traduzi-lo, que se relacionam diretamente com a capacidade de "ser forte". Entre os Canelos Runa, Guzmán (1997:46) traduz como respiração, vontade, vigor e compreensão interna, bem como nutrição espiritual, e enfatiza que está localizado igualmente na alma e no corpo. Uzendoski (2010:43; 68), trabalhando com os Napo Runa, traduz como espírito, aliento (ar que se respira, respiração), energia vital ou substância da alma. 
Ele também afirma que o samai se encontra dentro de todas as coisas que têm vida, de todos os seres viventes, espíritos, plantas, árvores, rochas, comidas especiais (como a aswa e também a carne, aycha) (Uzendoski 2010:43; 257). Norman Whitten (1985), etnógrafo que trabalhou com os Puyo Runa desde a década de 1970, traduz como "vontade" ou "força de vontade", a qual definiria a fortaleza interna da pessoa. Segundo Whitten (1985:108), "o samai de uma pessoa leva consigo algo da força de vontade dele mesmo [...] e algo do invisível (para os humanos quando estão acordados) que, ainda assim, é prova tangível de vigor interno". Mezzenzana (2015:14), por sua vez, traduz como "força de vida" e também como "respirar", além de apontar que samai, alma e conhecimento seriam conceitos intercambiáveis.

Até o momento, durante meu trabalho de campo, o samai foi traduzido como respirar, respiração, oxigênio e, ainda, como "trabalha muito" ou "pessoa que trabalha muito". O samai parece traduzir uma força vital "interna", mas impõe, ao mesmo tempo, uma reconsideração deste mesmo estado interno como oposição a um externo - o corpo (aycha, que pode também significar carne, animal etc., a depender do contexto de enunciação). É dizer, se mantivermos os termos corpo e samai, bem como interno e externo, estes não me parecem ser posições essenciais, substâncias ou partes independentes e separadas, mas sim mutuamente constitutivas - um corpo como entidade permeável, como também notou Guzmán (1997:51). O samai - dos vivos, dos mortos, de outros seres - é algo que se partilha de muitas maneiras. Uma pessoa como o yachak ou alguém que recebeu um paju (poder) ${ }^{22}$ de uma pessoa sábia pode facilitar sua circulação e curar doenças, por exemplo; alguns gestos, a respiração, a fala e o canto ou uma substância como a chicha (cerveja de mandioca) também ${ }^{23}$.

Gostaria, então, de pensar sobre a imbricação entre o samai e a capacidade de "ser forte" (ou conhecedor/a), enfatizada por minhas amigas, a alguns "produtos" - que podem não ser simplesmente produtos, no nosso sentido do termo. É a cotidiana e generalizada presença da mandioca transformada em chicha (consumida no dia a dia e em situações especiais, como em uma festa) que aqui me interessa: lideresas como sendo pessoas sinzhi, ou com forte samai, o mesmo tipo de pessoa que manteria uma chagra bem cuidada e ofereceria boa chicha, entre outras "coisas".

As chagras compreendem muitos cultivos, mas é

22 Paju é, grosso modo, um "poder" transmitido ou "pego" de um yachak ou de uma mulher sábia e/ou mais velha. Ver Uzendoski (2010), Mezzenzana (2015) e Whitten \& Whitten (2008).

23 Em Mezzenzana (2015) e Uzendoski (2010), a chicha aparece como o primeiro alimento que um bebê recebe e a bebida mais nutritiva para pessoas doentes. 
a mandioca doce e a banana (plátano, em castelhano, ou palanda, em kichwa) aquelas colhidas com mais frequência e que nunca faltam nas casas. $\mathrm{O}$ roçado é concebido como uma ocupação, modalidade e/ou forma de criatividade especificamente associada ao "feminino" e/ou "às mulheres": é delas, pertence a elas. No entanto, os homens também trabalham nas chagras: ajudam a abrir as roças e a mantê-las, bem como ajudam a carregar os cultivos para as casas. Essa “ajuda” não é pontual, no sentido de excepcional, mas sim faz parte de seus cotidianos. No entanto, se os homens podem não ir à chagra por qualquer razão e por vários dias seguidos, as mulheres nunca a abandonam. Vai-se diariamente cuidar de seu roçado ou, no caso das lideresas, quando há uma brecha na longa agenda de atividades da "vida organizativa".

A chagra é, ainda, um lugar de aprendizagem para as crianças. Desde muitos pequenos acompanham as mães, aprendem a manejar facões e a cultivar bons produtos. Explicou-me Hilda, por exemplo, que:

Desde muito pequenos já nos
ensinam. Minha neta já vai comigo
à chagra. As mulheres, desde muito
pequenas, tocam a terra, isso é o que
nós interpretamos, as mulheres estão
mais agarradas à terra, eu te digo, eu,
mulher, e a terra somos iguais, a terra
produz, e a mulher também produz
filhos. Por isso temos que respeitar,
meu corpo, meu sangue ninguém pode
negociar, a terra nos dá isso, Nunguli
nos dá isso... Nessa espiritualidade nós
acreditamos e vemos na prática.

Há pelo menos dois tipos de chicha: a doce, consumida geralmente no dia a dia; e a chicha forte, fermentada por cerca de quatro dias e, portanto, alcóolica, consumida geralmente em festas. Minhas/ Meus interlocutoras/es enfatizam que a mandioca transformada em chicha dá força, energia e vitalidade. Ouvi com frequência a frase "chicha é vida!" geralmente proferida por homens após ingerirem uma mocawa cheia de aswa. Particularmente marcante foi o comentário emocionado de um amigo, durante uma festa (minga), enquanto segurava uma linda mocawacheia de chicha e me contava sobre a luta do povo: "isso [apontando com os lábios para a chicha] é nossa vida. Os curas [missionários da igreja católica] queriam que deixássemos de tomar porque diziam ser pecado. Mas não deixamos" (grifo meu). Aprendi em meu próprio corpo a primeira lição quando se pisa em território kichwa: enquanto o álcool (trago) faz você sentir nada, a chicha faz você sentir alegria, faz você rir e celebrar a vida entre os parentes.

Em toda a região de Pastaza, a cerveja de mandioca é raramente consumida individualmente - há geralmente duas ou mais pessoas consumindo-a. Nos finais de semana, nas horas livres ou em momentos de festa, quase sempre se visita parentes que estão servindo boa chicha - a notícia se espalha rapidamente, geralmente proferida por homens. Tão importante quanto uma boa chicha são as tinajas ${ }^{24}$

24 Grande e decorada jarra de cerâmica, feita por mulheres e usada para armazenar chicha. 
e as mocawas finamente decoradas, bem como a forma - bela, bonita, adequada - através da qual a chicha é feita, servida e consumida, já que cada gesto parece evidenciar que a pessoa é conhecedora e propriamente runa (cf. Mezzenzana 2014, 2015) 25 .

Pensando com os/as Sarayaku Runa, é verdade que não é o sexo, mas a cerveja, a contrapartida feminina da comida ${ }^{26}$, pois fazer cerveja é uma atividade tão poderosa quanto matar animais (Erikson 1996); também é verdade que os homens participam da produção de cerveja, pois são responsáveis por derrubar a floresta, ajudar no preparo e manutenção da roça de mandioca, bem como no transporte dos cultivos das chagrasà casa; e que ambas as atividades - alimento/carne de caça e bebida/cerveja de mandioca - têm participação "feminina" e "masculina". Ainda

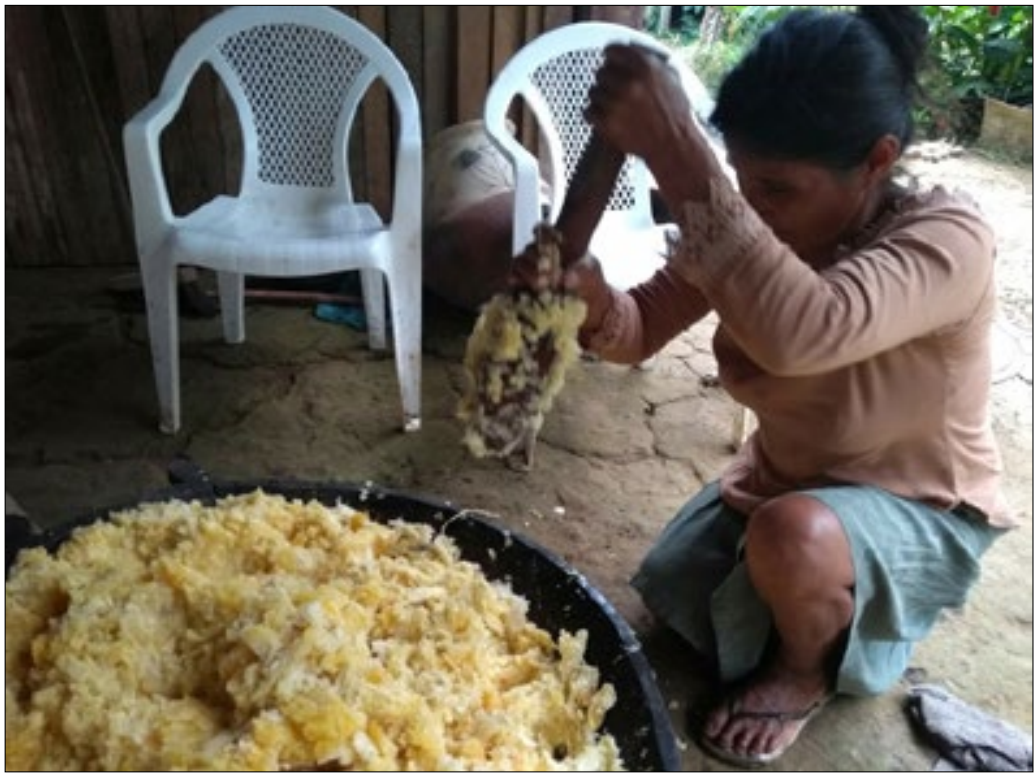

Figura 4 - Mulher kichwa de Sarayaku preparando chicha de mandioca. Foto: Marina Ghirotto Santos (2018). assim, eu diria que uma mulher é $a m u$ (dona) da carne (e outros alimentos) que recebe do marido, mas é mais ainda da sua cerveja de mandioca e da cerâmica ${ }^{27}$. Isso é verdade, apesar de também se dizer que, no caso da chicha, esta é feita principalmente para o desejo masculino e/ou de homens ${ }^{28}$. Os homens, por sua vez, nunca podem “doar” cerveja de mandioca como um presente,

25 Tão importante quanto ter ou não chicha é o como se fez. Oferecer boa chicha ou conseguir carne de caça e peixe, por exemplo, implica saber fazê-los da forma adequada, usando determinados artefatos (um macerador específico para a mandioca cozida, por exemplo); movendo-se de uma determinada forma ao servir a chicha nas mocawas, limpando as extremidades quando preciso e coordenando a quantidade que cada pessoa deve ingerir; movendo-se com destreza no mato ou metendo-se fundo no rio para buscar peixes, usando os arpões com máxima habilidade, beleza e força. Sobre a importância da ideia de forma e movimento, ver, principalmente, o trabalho de Mezzenzana (2015).

26 Pensando aqui carne de caça ou peixe, mas, eu diria, também alguns alimentos que não são produzidos em Sarayaku, roupas e outros objetos.

27 Seria tema para um outro artigo pensar sobre situações onde mais de uma mulher é dona de uma mesma chicha, como presenciei na casa de Mirian.

28 Há também um idioma de sedução e conquista que envolve o brindar (servir, oferecer) a chicha, mas que não poderei abordar aqui. 
como as mulheres fazem com carne ou peixe, quando decidem dar a outros parentes ou vizinhos. Mesmo que o marido ou outro homem também ofereça a chicha quando há visitas em sua casa (e o fazem com bastante frequência), ou (muito) eventualmente peguem chicha diretamente das tinajas para servirem-se, em última instância a chicha parece sempre pertencer à mulher (às vezes, chamada de mãe da chicha), que é quem transforma a mandioca cozida com sua saliva ${ }^{29}$.

As ligações entre uma pessoa, seu corpo-samai, algumas das substâncias que produz (ou lhe são parte) e a relação com outros seres aparecem também em mitos sobre espíritos ou seres nos quais coisas, habilidades e forças são transmitidas, geralmente de mulher para mulher e de homem para homem, tal como é possível entrever na fala de Hilda anteriormente mencionada. Há três seres relacionados de maneira especial ao gênero de uma pessoa: Nunguli, Chagra Amu (dona ou chefa da chagra) ou Chagra Mama (mãe da chagra), uma habilidosa agricultora que mantém todos os lugares cultivados; Manga Allpa Mama, mãe do barro, também referida como apamama ou avó do barro ou, ainda, como dona do barro, que detém o conhecimento necessário para fazer cerâmica; e
Amasanga (ou Amazanga), um espírito masculino ligado ao domínio da selva (sacha), dono e líder de todos os animais da floresta. No caso da chagra, é com Nunguli que é preciso estabelecer uma relação amistosa para que a colheita seja boa: cantos e lindas mocawas com uma mistura de plantas devem ser a ela oferecidas no momento do plantio ${ }^{30}$.

Com estas breves observações, gostaria apenas de enfatizar a centralidade desta substância na socialidade runa: sem chicha não se faz bons, importantes e grandes conversatórios, não se cultiva relações, não se fazem pessoas fortes e propriamente runa, não se vive uma boa vida. Uma casa não pode ficar sem chicha; uma chagra não pode ficar sem mandioca, para depois ser transformada em chicha; uma presidenta não pode ficar sem chicha, como mencionou Mirian. A chagra, a mandioca e a chicha parecem envolver as mulheres runa, seus corpos e suas substâncias em uma espécie de fluxo de relações com "a terra" e seres - e, inversamente, tornam essas próprias relações aparentes, cultivando-as. É a imagem decorrente de corpos como "territórios de vida", da capacidade agentiva de criação e de transformação da mandioca em chicha, da chicha em energia e

29 Explicaram-me também que a saliva dos homens é muito forte e estragaria a chicha, se fossem eles a mascá-la.

$30 \mathrm{Na}$ literatura da região, os nomes de seres ou espíritos femininos foram descritos de forma variada. Whitten (1985) utiliza Nunghui para designar tanto Chagra Mama como Allpa Manca Mama. Segundo Guzmán (1997), as pessoas em Canelos normalmente usam os dois últimos nomes, enquanto em Sarayaku usam mais frequentemente Nunguli- uma adaptação kichwa ao contato com pessoas falantes de línguas jivaroanas (ver Descola 1988). 
vitalidade e outras "coisas" de que são capazes esses corpos e substâncias, externalizados nas "coisas" boas e bonitas que faz e mantêm, que gostaria de reter (cf. Lotierzo 2018). Uma relação em que uma multiplicidade de pessoas e territórios (ou chagra, ou chicha, ou samai) estão juntas, ecoando a poderosa proposição de Viveiros de Castro (2015) de um perspectivismo ameríndio que inspira modos de existência pautados na ideia de que a cultura é única e os corpos são múltiplos.

Alegações como a de que "a mulher é mais ligada à terra", à primeira vista, nos afastariam de alguns argumentos, feministas e ecofeministas, que criticaram a tendência em ligar as mulheres ao meio ambiente e à natureza - ou àquilo que nós, modernos-ocidentais, entendemos por esses termos (cf. Maizza \& Vieira, 2018). Porém, gostaria de sugerir que este não me parece ser o caso. A importância dada à capacidade - aqui, das mulheres - de fazerem "coisas" a partir de seus corpos-terra, eles mesmos matrizes de transformações, não parece estar fincada em uma aproximação das mulheres ao polo da natureza porque corpo, mulher e natureza, aqui, podem ser apenas parcialmente o que está em jogo ou podem ser "excedidos" (exceeded) (de la Cadena 2015, 2018). Como já previram outras/ os antropólogas/os, os regimes de socialidade indígena se assentam sobre os corpos e os processos corporais, cuja existência e evolução dependem da agência humana (e provavelmente "mais que humana” também), e não em leis impessoais da "natureza" (Belaunde 2005, 2006; McCallum 2001, 2013; Overing 1986; Viveiros de Castro 2015). Ainda, e como nos lembra Isabelle Stengers (2008:41), “o que importa é sair de uma postura de 'tolerância' e dar a esta [afirmação] o poder de nos fazer 'hesitar' sobre nossas próprias condições de pensamento".

Sobre esta questão, vejamos ainda algumas traduções que aparecem na proposta Kawsak Sachal Selva Viventee podem nos ajudar a pensar. Apresentada publicamente em um grande evento de lançamento na cidade de Quito, em julho de 2018, configura um dos maiores esforços ao qual se dedicam atualmente vários líderes e lideresas de Sarayaku. A proposta explica e traduz ao mundo - especialmente, ao mundo dos não indígenas - que o território é Kawsak Sacha, um ser vivo com consciência, constituído por todos os seres da selva, desde os mais infinitesimais até os maiores e mais supremos. Inclui todos os seres do mundo animal, vegetal, mineral, espiritual e cósmico, em intercomunicação com os seres humanos. Esses seres, desde as menores plantas até os mais supremos que protegem a selva, são pessoas (runaguna) que habitam as cachoeiras, as lagoas, os pântanos, as montanhas, os rios, as árvores e outros lugares do território, vivem em comunidade e desenvolvem sua vida de maneira semelhante ao ser humano. Não é uma simples crença ou um ideal conservacionista; 
é um chamado às pessoas para aprenderem a sentir essa realidade no seu mais íntimo ser. "Isso só será possível se aprendemos a escutar e dialogar com esses outros seres que formam parte de uma conversação [diálogo, conversa] cósmica que vai muito além de nós, humanos (vivos)", diz o documento apresentado em Quito (Sarayaku 2018:s/p). A proposta também exige o reconhecimento do mesmo caráter de sujeitos jurídico-políticos conferido aos seres humanos a outros seres viventes, uma nova categoria de conservação dos territórios indígenas e a declaração de seus territórios como livres, em perpetuidade, de projetos extrativistas - petroleiros, mineiros, madeireiros etc.

Quando perguntei porque a proposta chama-se Kawsak Sacha e não, por exemplo, Kawsak Chagra, ouvi uma resposta uníssona: sacha é tudo, a chagra está incluída. O território é "Sacha Runaguna", isto é, "todos os habitantes da selva, visíveis e invisíveis, femininos e masculinos”. A chagra e o sacha não são simplesmente meio ambiente ou entidades biológicas externas e socializáveis; ao contrário, e mais ainda, elas próprias produzem socialidades.

\section{PENSANDO ENTRE MULHERES}

A alegação de que "eu, mulher, e a terra somos iguais"; de que o território é Kawsak Sacha e não "recursos"; e as afirmações da centralidade dos conversatórios cósmicos entre humanos e entre humanos e mais que humanos me fazem observar que o que é declarado (pelo Estado, por empresas, pelo mundo moderno) como natureza e humanos, entre os/as Sarayaku Runa, não é apenas promulgado como tal. Nos pronunciamentos aqui relatados, "terra" e "território", sacha e chagra, podem fazer referência tanto a um pedaço de terra sob a jurisdição do Estado equatoriano quanto a uma entidade que emerge por meio de práticas de vida que podem, por exemplo, tornar pessoas parentes e/ou contíguas a terra, a cultivos, a substâncias, a rios etc.; é dizer, o que define território depende do mundo que o pronuncia, das relações das quais ele emerge. Essa relação - em que as pessoas e o território estão juntas - excede as possibilidades dos humanos modernos e da natureza moderna, bem como as relações modernas entre eles, sem no entanto excluí-las. O que está em jogo, portanto, é, também, uma concepção distinta de vida (e, talvez, de não vida, como discute Povinelli 2016).

Estou aqui pensando, principalmente, com Marisol de la Cadena $(2015,2018)$. A autora discute o que chama de "processo de criação de mundo", por meio do qual mundos heterogêneos, que não se fazem com uma divisão entre humanos e não humanos, natureza e cultura, são obrigados a operar com essa distinção ao mesmo tempo em que a excedem. Recupero esta discussão porque me parece que esta mesma lógica parece operar entre os Sarayaku Runa, sobretudo quando observamos as lutas antiextrativistas, os esforços de tradução 
envolvidos na proposta Kawsak Sacha e mesmo nas reflexões que mulheres (e homens) fazem a respeito da permeabilidade entre a mulher e a terra. Porém, gostaria de ressaltar aqui um outro movimento, que me parece ser análogo, mas diz respeito à "questão de gênero": mundos heterogêneos, que não se fazem com uma divisão (oficiosa, é preciso dizer, no caso dos modernos, embora queira aparecer como oficial) estrita entre homens e mulheres (a dicotomia sexogênero como análoga à de natureza-cultura), são obrigados ou, eu diria, escolhem operar com essa distinção mais ou menos rígida ao mesmo tempo que a excedem, ou a questionam - "mulher é isso, homem é aquilo"; "mulher faz isso, homem faz aquilo".

Pensando sobre a posição de liderança, apenas afirmar que a mulher, longe de ser coadjuvante, é a contraparte fundamental da liderança masculina e que, portanto, interrogar-se sobre mulheres lideresas seria um não problema não parecia ser suficiente neste contexto (cf.Perrone-Moisés 2015). Hilda e Ena, por exemplo, são mulheres separadas e viúvas e não representam exatamente essa contraparte; Mirian, por sua vez, seria a própria parte. Liderança e política entre os runa, portanto, não parece estar circunscrita nem à figura de um homem, ou do "masculino", nem à figura de um casal - homem e mulher como unidade produtora e reprodutora -, pois outros arranjos podem acontecer. Mas o que também gostaria de enfatizar é que não é exatamente o casamento entre duas pessoas que é determinante, mas sim a mistura adequada de diferenças (e de semelhanças) que mantém as relações de reciprocidade e a existência social - homens, mulheres, as "coisas" que fazem e as "coisas" que os/ as fazem, incluindo relações entre pessoas do mesmo gênero e parceiros de gênero diferente (Overing 1986; Belaunde 2006). É por isso que um kuraka, por exemplo, pode não ser casado e ter em sua mãe ou irmãs alguém que lhe apoie para servir chicha.E, talvez por isso também, Mirian manifeste que o problema não éser liderança como “mulher solteira”, viúva separada, etc., mas justamente o contrário: ser casada, pois isto implica momentos de ausência no âmbito da casa.

Assim, ao me voltar aos chefes - ou, para manter os termos nativos, às lideranças ou dirigentes/as - não gostaria de haver sido entendida como um voltar "à política dos homens" (considerando-a, ainda, como mais relevante), ou a algumas mulheres que ocupam lugares tidos como "masculinos" em detrimento daquelas que não são lideranças, como acontece em muitos outros contextos. Pelo contrário, é justamente essa imbricação que busco evidenciar: as mulheres o fazem - e me parece, espera-se que o façam - a partir de sua perspectiva, "da mulher", ou de uma agência "feminina", e esta está necessariamente imbricada à dos homens.

Mas olhemos, ainda, para o desconforto manifestado pelas mulheres em relação à ocupação 
de posições de liderança. Que alguém reflita, critique, reinvente o que o gênero ou outra "coisa" faz, em um esforço de buscar fazê-lo algo diferente, não é uma característica exclusiva deste povo. Dito isso, em muitos momentos, elas parecem interpretar determinadas atitudes ou questões (como a sobreposição de tarefas, despreparo, menos domínio da língua dos brancos etc.) como um "problema" que viria de homens para mulheres (muitas vezes, fazendo uso do termo "machismo") -, o que as aproximaria de um certo discurso feminista.

No entanto, isso também coloca uma "questão" para a análise aqui empreendida, pois não apenas a ideia de uma dominação "natural" do homem sobre a mulher, do público e do político sobre o doméstico e o privado e da aproximação da mulher a algo que chamaríamos de "natureza" não funciona ou é excedida nesse contexto, mas também o que se entende por um "problema de gênero", aqui, pode não estar identificado exatamente com o que nós entendemos por este termo - é dizer, com uma condição desigual a priori ligada à dominação e à opressão universal de homens sobre mulheres como análoga à dicotomia natureza vs. cultura (Strathern 2006; Overing 1986; Haraway 1995; Butler 1999; Maizza 2017). Não me considero apta a dizer se essas mulheres são ou não feministas, ou se o que fazem e falam é feminismo ou não. Na verdade, esta não me parece ser uma questão que cabe a mim discutir. Ainda assim, poderia apenas sugerir que as críticas parecem ser precisamente uma ação/idioma próprio das mulheres que povoa as políticas (e as lutas, a "vida organizativa", a cotidianidade etc.) do que apenas, ou exclusivamente, uma mudança (ou demanda por mudança) do papel das mulheres na socialidade runa - no sentido de subjugadas e excluídas a protagonistas, um problema próprio do mundo moderno-ocidental.

Sugiro que as falas e os eventos que busco trazer à tona, aqui, evidenciam o papel decisivo dos/das fazedores/as de conversa e de conhecimento - de coletivos, enfim: as lideresas e os líderes, aqueles que puxam a fala, que aconselham, que cantam, que doam (comida, dinheiro, tempo, espaço etc.), que ajudam, que fazem circular energia, que fazem ver a fortaleza que são, que fazem ver seus conhecimentos e os conhecimentos do povo. É pelo manejo engenhoso da palavra e de tudo o que faz vida - como a chicha - que estabelecem seu prestígio, autoridade e/ou influência, ainda que estas nada tenham de coerção (Sztutman 2018). Recuperar este lugar criador, seja da linguagem ou de substâncias que "fazem ver" o conhecimento e a força de uma pessoa, pode ajudar a vislumbrar lugares agenciados por mulheres que não se limitam ao campo do doméstico e/ou ao privado 
como oposição ao público ${ }^{31}$. No entanto, esta alegação não é exatamente minha, ou não parte de uma preocupação exclusivamente minha (ou moderna, ou ocidental); ao contrário, enfatizar que "eu não me tranco em casa, eu me organizo", como fez Hilda; ou que "eu não sou uma mulher de ficar em casa, pois saio cedo para ir à chagra", como faz Ena, não é o mesmo que dizer que a casa é uma esfera desvalorizada; ao contrário, é extremamente valorizada por todas as pessoas, e estas e outras falas apenas sinalizam que a casa não é a única esfera onde lhes importa estar ${ }^{32}$.

Assim, me parece que levar adiante um coletivo, fazer conversatório e/ou fazer ver o conhecimento - se permanecemos perseguindo a categoria nativa de política - a partir da posição de liderança só é possível na medida em que, por exemplo, a mandioca e a chicha, partes de uma pessoa conhecedora e forte, se fazem ver, e isto se entrelaça (ou não está separado) da política dos grandes conversatórios e da luta, na linha de frente contra o Estado, empresas e o mundo moderno, das quais as mulheres (e os homens) participam, ainda que de forma diferente - ou justamente por formas diferentes. Em suma, cuidando dos filhos, da família, da roça, fazendo uma boa chicha e também liderando grandes e importantes conversatórios se faz (cosmo)política, se faz pessoas e conhecimento.

Por fim, poderíamos entrever uma conexão parcial entre as reflexões das mulheres runa, as ficções persuasivas que tenho tentado desenhar e as considerações feitas por algumas pesquisadoras feministas e politicamente engajadas, como Julieta Paredes, Isabelle Stengers, Starhawk, a própria Marisol de la Cadena, Donna Haraway, entre tantas outras, que denunciam a operação que desqualifica e submete as mulheres ao campo do que nós entendemos por natureza, de um lado, e aquela que submete a vida na terra - e a própria "terra" - ao mantê-la disponível à manipulação (e excepcionalidade) humana (ou de alguns humanos). Pensando especificamente com uma delas, Isabelle Stengers (2014, 2008, 2017), a proposta cosmopolítica e as políticas feministas denunciam as formas convencionais de "fazer política" e "fazer ciência" - marcadas pelo confisco da vida do domínio da política e, inversamente, da política do domínio da ciência - e insistem na presença de "humanos outros"

31 Como também observou Lea (1999), o trabalho de Strathern (2006), de grande repercussão na etnologia, tem demonstrado que a associação das mulheres com a esfera doméstica é tautológica e acaba mascarando formas de socialidade que extrapolam a mesma esfera doméstica.

32 Com esse comentário, não pretendo inverter uma determinada lógica de dominação, até porque minhas/meus interlocutoras/es são enfáticas/os em pontuar que a luta das mulheres é, antes de tudo, pelo território e pela vida e está junto com os homens. 
na feitura de mundos e modos de existência que podem eventualmente - diplomaticamente - se articular. Nesta lógica, as muitas formas-potências de vida - aqui, o samai, a chicha, a terra etc. seriam igualmente recolocadas na agenda de discussões sem, contudo, serem reificadas como "natureza" ou um modo moderno-ocidental de conceber e reunir os seres de forma hierarquizada e apartada do mundo da política.

\section{REFLEXÕES FINAIS}

O "gênero" apareceu, aqui, em uma incômoda inflexão que não chego a resolver, mas gostaria de explicitar: meu trabalho tem sido (auto)identificado como próximo "às questões de gênero" (“apenas”) por falar com mulheres. No entanto, tomar esta perspectiva como um "dado" me parece perigoso, pois implicaria, então, a ideia de que "mulher" é o gênero marcado; que há uma autoevidência de que existem mulheres (e homens) por toda a parte; e que "mulher", entre os runa, quer dizer a mesma coisa que nós queremos dizer com esse termo - no caso, uma mulher cisgênero? Não foi meu objetivo discutir o que o gênero é para meus amigos e amigas, mas sim dedicar atenção para o que isto, que nós chamamos de gênero, faz ou pode fazer - podendo ser, ao mesmo tempo, mobilizado $e$ excedido (de la Cadena 2015, 2018).

Mas gostaria de tomar para mim o alerta de Pereira de Araujo (2018:74): o de manter como um problema o fato de que a linguagem pela qual falamos (ou eu falo) sobre gênero, entre euramericanos e ameríndios, esbarra frequentemente em um limite que é a diferença sexual concebida como binária. É dizer, o "gênero" e/ou "problemas de gênero" são muito facilmente identificados como "problemas" entre homens e mulheres. É por isso que usei, em alguns momentos, os termos homens, mulheres, feminino e masculino entre aspas. Mas isso não retira minha total responsabilidade em seguir utilizando-os; apenas sinaliza minha própria incapacidade de ir além deles, ou minha limitação em não os discutir em profundidade aqui.

Parece que restaria imaginar o porquê, mesmo se a categoria de mulher não é tomada como um a priori, ela permanece como o centro descritivo que permite a qualificação de outras categorias (aqui, a própria chicha de mandioca) como sendo, por exemplo, “femininas" - ou "de mulheres". Em julho de 2019, após escutar a apresentação de um antropólogo de Pacayaku, povo vizinho de Sarayaku, em um congresso onde ambos apresentamos trabalho, a necessidade dessa imaginação ficou ainda mais evidente. Ele nos contou, entre outras coisas, que as pessoas warmipangui - termo em kichwa para designar relações homossexuais e/ou homoafetivas, intercambiado com a palavra gay e cuja tradução 
seria "se parece com mulher" - podem ser tão responsáveis quanto as mulheres pela circulação da chicha, pela manutenção das chagras e pelo cuidado com os filhos, por exemplo. Se é verdade que as posições "homem" e "mulher" parecem ser apenas parcialmente reversíveis; e que a chicha, por exemplo, é uma esfera concebida e associada ao feminino e/ou às mulheres; é também verdade que "o feminino" não é agenciado, ou não agencia, apenas mulheres - como seres do sexo biológico feminino. É dizer, meu trabalho ainda aborda o gênero na perspectiva da heterossexualidade, sendo a homossexualidade e/ou homoafetividade mencionada apenas aqui, ao final ou como uma observação adicional - como em tantos outros trabalhos ${ }^{33}$.

Neste sentido, o que poderia apenas dizer, em consonância com Pereira de Araujo (2018), é que talvez a preocupação dos/as Sarayaku seja em como produzir gente (runa) adequada, isto é, capaz de adotar e manter a mesma perspectiva humana dos demais do grupo. Se falam insistentemente sobre homens e mulheres enquanto produzem novos homens e mulheres, talvez seja porque o gênero é um dos discursos pelo qual diagramam, no tempo atual, as linhas de possibilidades que atravessam essa produção de gente de verdade, o jeito apropriado de fazer pessoas ligado às possibilidades de criar relações específicas e um tipo particular de corpo - ou conhecimento.

\section{AGRADECIMENTOS}

O presente artigo é parte de minha tese de doutorado, em andamento no Programa de PósGraduação em Antropologia Social (PPGAS), da Universidade de São Paulo (USP). Uma primeira versão deste texto foi apresentada no Simpósio Temático "Mulheres indígenas e suas coexistências: inscrições etnográficas da relação entre gênero e terra", no $3^{\circ}$ Congresso Internacional Povos Indígenas da América Latina (CIPIAL), realizado em julho de 2019, na Universidade de Brasília. Agradeço às organizadoras, Sandra Benites, Nicole Soares e Ana María Ramo y Affonso, bem como às participantes do ST, pelos valiosos comentários. Agradeço também à Fabiana Maizza, pelas sugestões fundamentais para a discussão aqui apresentada; aos meus orientadores, Renato Sztutman e Salvador Schavelzon; e, por fim, às pareceristas da Amazônica - Revista de Antropologia. Minha pesquisa de doutorado conta com o apoio da Fundação de Amparo à Pesquisa do Estado de São Paulo (FAPESP), processo número 2017-17805-2.

33 Felizmente, esta vem sendo alvo de atenção aprofundada nos últimos anos (cf. McCallum 2013, Fernandes 2013, entre outros, embora Clastres, por exemplo, já havia refletido sobre o assunto em "O arco e o cesto", em "A sociedade contra o Estado", 2012 [1934-77]). 


\section{REFERÊNCIAS}

Belaunde, L. E. 2005. El recuerdo de Luna: género, sangre y memoria entre los pueblos amazónicos. Lima: Universidad Nacional Mayor de San Marcos.

Belaunde, L. E. 2006. A força dos pensamentos, o fedor do sangue. Hematologia e gênero na Amazônia. Revista de Antropologia 49(1):205-243. DOI: http://dx.doi.org/10.1590/S0034-77012006000100007.

Becker, M. 2015. ¡Pachakutik! Movimientos indígenas, proyectos políticos y disputas electorales en el Ecuador. Quito: Abya Yala e Flacso Ecuador.

Butler, J. 1999. Gender trouble: feminism and the subversion of identity. New York: Routledge.

Chávez, G., R. Lara, e M. Moreno, 2005. Sarayaku: el pueblo del cenit identidad y construcción étnica informe antropológico-jurídico sobre los impactos sociales y culturales de la presencia de la Compañía CGC en Sarayaku. Quito: FLACSO/ CDES.

CIDH. 2012. Pueblo indígena kichwa de Sarayaku vs. Ecuador. Sentencia de 27 de junio de 2012. Disponível em: http://www.corteidh.or.cr/docs/casos/articulos/seriec_245_esp.pdf. Acesso em: 14 ago. 2019.

Clastres, P. 2012 [1934-1977]. A sociedade contra o Estado. São Paulo: Cosac Naify.

Codeso. 2007. Provincias del Ecuador. Disponível em: http://www.codeso.com/TurismoEcuador/ Mapa_Pastaza.html. Acesso em: 14 ago. 2019.

De la Cadena, M. 2015. Earth beings: ecologies of practice across Andean Worlds. Durham: Duke University Press.

De la Cadena, M. 2018. Natureza incomum: histórias do antropo-cego. Revista do Instituto de Estudos Brasileiros (69):95-117. DOI: https://doi.org/10.11606/issn.2316-901X.v0i69p95-117. 
Descola, P. 1988 La selva culta, simbolismo y praxis en la ecología de los Achuar. Quito: Abya Yala-IFEA.

Ecuadorec. 2018. Mapa del Ecuador (Físico, Político, Turístico) Provincias y Capitales. Disponível em: https://ecuadorec.com/mapa-ecuador-fisico-politico-turistico/. Acesso em: 14 ago. 2019.

Erikson, P. 1996. La Griffe des Aieux: Marquage du Corps et Demarquage Ethniques chez les Matis d'Amazonie. Paris/Leuven: Peeters.

Fernandes, E. 2013. Homosexualidades indígenas y descolonialidad: algunas reflexiones a partir de las críticas two-spirit. Tabula Rasa (20):135-157.

Ghirotto, M. 2015. A plurinacionalidade em disputa: Sumak Kawsay, autonomia indígena e Estado plurinacional no Equador. Dissertação de Mestrado, Pontifícia Universidade Católica de São Paulo, Departamento de Ciências Sociais, São Paulo.

Gow, P. 1993. Gringos and wild Indians. Images of history in Western Amazonian cultures. L'Homme 33(126-128):327-347.

Guzmán, M. A. 1997. Para que la yuca beba nuestra sangre. Trabajo, género y parentesco en una comunidad kichwa de la Amazonía Ecuatoriana. Quito: Abya Yala/CEDIME.

Haraway, D. 1995. Saberes localizados: a questão da ciência para o feminismo e o privilégio da perspectiva parcial. Cadernos Pagu (5):7-41.

Hill, J. 1996. Introduction: ethnogenesis in the Americas, 1492-1992, in History, power, and identity: ethnogenesis in the Americas, 1492-1992. Editado por J. D. Hill, pp. 26-45. Iowa City: University of Iowa Press.

Hudelson, J. E. 1987. La cultura quichua de transición. Su expansión y desarrollo en el Alto Amazonas. Quito e Guayaquil: Museu Antropológico/Banco Central/Abya Yala. 
Kohn, E. 2013. How forests think: toward an anthropology beyond the human. California: University of California Press.

Kopenawa, D., e B. Albert. 2015. A queda do céu: palavras de um xamã yanomami. São Paulo: Companhia das Letras.

Lea, V. R. 1999. Desnaturalizando gênero na sociedade Mebengôkre. Revista Estudos Feministas 7(12):176-194.

Lotierzo, T. 2018. Dos corpos, a terra: notas sobre a criatividade no trabalho de Rosa Tisoy. Campos 19(1):59-85.

Maizza, F. 2017. De mulheres e outras ficções: contrapontos em antropologia e feminismo. ILHA 19(1):103-135. DOI: https://doi.org/10.5007/2175-8034.2017v19n1p103.

Maizza, F., e S. A. Vieira. 2018. Introdução ao dossiê Ecologia e Feminismo: criações políticas de mulheres indígenas, quilombolas e camponesas. Campos 19(1):9-15. DOI: http://dx.doi.org/10.5380/ cra.v19i1.64071.

McCallum, C. 1999. Aquisição de gênero e habilidades produtivas. Revista Estudos Feministas 7(1-2):1-19.

McCallum, C. 2001. How real people are made: gender and sociality in Amazonia. Oxford: Berg Publishers.

McCallum, C. 2009. Becoming a real woman: alterity and the embodiment of Cashinahua gendered identity. Tipití: Fournal of the Society for the Anthropology of Lowland South America 7(2):42-66.

McCallum, C. 2013. Nota sobre as categorias "gênero" e "sexualidade" e os povos indígenas. Cadernos Pagu (41):53-61. DOI: http://dx.doi.org/10.1590/S0104-83332013000200006. 
Mezzenzana, F. 2014. Doing it like real Runa women and men. A Runa ceremonial festival. Tipití: Fournal of the Society for the Anthropology of Lowland South America 12(1):61-79.

Mezzenzana, F. 2015. Living through forms: similarity, knowledge and gender among the Pastaza Runa (Ecuadorian Amazon). Tese de Doutorado, London School of Economics and Political Science, Departamento de Filosofia, Londres.

Orr, C., e B. Wrisley, 1981 [1965]. Vocabulario Quichua del Oriente del Ecuador. Quito: Instituto Linguístico de Verano/Ministerio de Educación Pública.

Overing, J. 1986. Men control women? The 'Catch 22 ' in the analysis of gender. International fournal of Moral and Social Studies 1(2):135-156.

Pereira de Araujo, B. 2018. Fecundações cruzadas. Gêneros ameríndios e incursões antropológicas. Dissertação de Mestrado, Universidade Federal de São Paulo, Departamento de Ciências Sociais, São Paulo.

Perrone-Moisés, B. 2015. Festa e guerra. Tese de livre docência, Universidade de São Paulo, Departamento de Antropologia Social, São Paulo.

Povinelli, E. A. 2016. Geontologies. A requiem to late liberalism. Durham: Duke University Press.

Reeve, M. E. 2002. Los Quichua de Curaray: el proceso de formación de la identidad. Quito: Abya-Yala.

Reeve, M. E. 2014. Amazonian Quichua in the Western Amazon. Regional Interaction Sphere. Tipití: Journal of the Society for the Anthropology of Lowland South America 12(1):14-27.

Rosaldo, M., e L. Lamphere. 1974. Introduction, in Woman, culture and society, Editado por M. Rosaldo, e L. Lamphere, pp. 1-16. Stanford: Stanford University Press. 
Sarayaku. 2018. Declaración Kawsak Sacha-Selva Viviente, Ser Vivo y Conciente, Sujeto de Derechos. Disponível em: http://sarayaku.org/propuestasprogramas-y-proyectos/. Acesso em: 16 ago. 2019.

Siren, A. 2014. History of natural resource use and environmental impacts in an interfluvial upland forest area in western Amazonia. Fennia 192(1):36-53.

Stengers, I. 2008. Experimenting with refrains: subjectivity and the challenge of escaping modern dualism. Subjectivity 22: 38-59. DOI https://doi.org/10.1057/sub.2008.6.

Stengers, I. 2014. La propuesta cosmopolítica. Revista Pléyade 14:17-41.

Stengers, I. 2017. Reativar o animismo. Belo Horizonte: Chão da Feira. Caderno de Leituras 62.

Strathern, M. 2004. Partial connections. Updated Edition. Walnut Creek: Altamira Press.

Strathern, M. 2006. O gênero da dávida: problemas com as mulheres e problemas com a sociedade na Melanésia. Campinas: Editora da Unicamp.

Sztutman, R. 2018. O lugar (cosmopolítico) da linguagem: perspectivas das terras baixas sul-americanas. Relatório III (Final). Diplomacias cosmopolíticas nas terras baixas sul-americanas - Exercícios de comparação etnográfica. No prelo.

Uzendoski, M. 2010. The Napo Runa of Amazonian Ecuador. Quito: Abya Yala.

Uzendoski, M., e N. E. Whitten, 2014. From “acculturated Indians” to “dynamic Amazonian Quichuaspeaking peoples". Tipití: Journal of the Society for the Anthropology of Lowland South America 12(1):1-13.

Viveiros de Castro, E. 2004. Perspectival anthropology and the method of controlled equivocation. Tipiti: Fournal of the Society for the Anthropology of Lowland South America 2(1):2-20. 
Viveiros de Castro, E. 2015. Metafísicas canibais. São Paulo: Cosac Naify.

Whitten, N. E. 1985. Sicuanga Runa: the other side of development in Amazonian Ecuador. Urbana: University of Illinois.

Whitten, N. E., e D. S. Whitten. 2008. Puyo Runa: imagery and power in modern Amazonia. Urbana/ Chicago: University of Illinois Press. 